\title{
Temporal and spatial changes of seagrass meadows in a Mediterranean coastal lagoon
}

\section{Évolution spatiotemporelle des herbiers à phanérogames dans une lagune côtière méditerranéenne}

\author{
Sylvia Agostini ${ }^{\mathrm{a}, \mathrm{b}, *}$, Bernard Marchand ${ }^{\mathrm{a}}$, Gérard Pergent ${ }^{\mathrm{c}}$ \\ ${ }^{\text {a } M e d i t e r r a n e a n ~ E c o s y s t e m s ~ L a b o r a t o r y, ~ U n i v e r s i t y ~ o f ~ C o r s i c a, ~ B P ~ 52, ~} 20250$ Corte, France \\ b Office de l'Environnement de la Corse, avenue Jean Nicoli, 20250 Corte, France \\ " Équipe "Écosystèmes Littoraux", University of Corsica, BP 52, 20250 Corte, France
}

Received 8 April 2002; received in revised form 16 September 2002; accepted 18 September 2002

\begin{abstract}
Aerial photographs and in situ data of the Urbinu Lagoon (one of the largest and deepest ponds in Corsica, Mediterranean Sea) permit the establishment of a cartography of its aquatic benthic assemblages and types of sea-beds. It was possible to distinguish in the photographs submerged structures such as: sand, pebbles, mud and seagrass meadows. Seagrass beds were the predominant vegetation type in this lagoon (comprising 14-29\% of the total area depending on the year studied), and their distribution was incorporated into a geographical information database, and then compared with historical data. Temporal and spatial change in seagrass meadows was assessed between 1990 and 1997. Change in total extent was evaluated through a map to map comparison of data interpreted from image processing using colored aerial photographs (1990, 1994 and 1997). The overall net change was a 12\% decrease between 1990 and 1994 and a $16 \%$ increase between 1994 and 1997. These observations imply that regressions are not irreversible over the past 7 years, and show that seagrass meadows in this area have been stable despite environmental perturbations, since the lost zones were recolonized.
\end{abstract}

(C) 2002 Ifremer/CNRS/IRD/Éditions scientifiques et médicales Elsevier SAS. All rights reserved.

\section{Résumé}

Des photographies aériennes et des observations sur le terrain permettent de cartographier les biocénoses aquatiques et les types de fonds au sein de l'étang d'Urbinu (un des plus grands et des plus profonds étangs de Corse, île de Méditerranée). Grâce à ces photographies, il est possible de délimiter les structures sous-marines présentes comme les fonds sableux, les fonds rocheux, les fonds vaseux et les herbiers à phanérogames. Le type de végétation prédominant dans cette lagune sont les phanérogames qui occupent 14 à $29 \%$ de la surface totale selon les années. Leur distribution a été intégrée dans une base de données afin de pouvoir être comparée avec des données historiques. L'évolution spatiotemporelle de ces herbiers à phanérogames a été évaluée entre 1990 et 1997. L'importance des changements a été estimée grâce à une comparaison de cartographies réalisées par traitement d'image à partir de photographies aériennes couleurs (de 1990, 1994 et 1997). Le changement net global était de $12 \%$ de pertes de surface entre 1990 et 1994 et de $16 \%$ de gain entre 1994 et 1997. Ces observations impliquent que les régressions ne sont pas irréversibles au cours de ces sept dernières années et montrent que les herbiers à phanérogames ont été stables dans cette zone en dépit des perturbations environnementales, puisque les zones perdues ont été recolonisées.

(C) 2002 Ifremer/CNRS/IRD/Éditions scientifiques et médicales Elsevier SAS. Tous droits réservés.

Keywords: Seagrasses; Mediterranean lagoon; Image processing; Change detection

Mots clés: Phanérogames; Lagune méditerranéenne; Traitement d'image; Évolution d'écosystème

\footnotetext{
* Corresponding author.

E-mail address: agostini@univ-corse.fr (S. Agostini).
} 


\section{Introduction}

Seagrass beds are among the most important benthic communities in temperate coastal areas, where they have a fundamental ecological role (Kuo et al., 1996; Cambridge and Hocking, 1997). Seagrass is known to be an indicator and integrator of environmental variations, and not only as one simple taxon (Grauby et al., 1991; Pergent, 1991). The highlighting of such variations supposes a sufficient lapse of time so that a phenomenon can be perceived and a regular follow-up made to assess cyclic direct relations between environmental phenomena and benthic populations. As long-term changes result from disturbances of anthropogenic origin or climatic variations (Rasmussen, 1977; Den Hartog, 1987), the reference of the original state is necessary; a good knowledge of the biotopes and their history is thus essential. However, precise mapping of a disturbed area offers another means of obtaining evidence of natural or anthropogenically induced disturbances in time and space.

This work addresses the suitability of aerial photographs interpreted at a resolution of $1 / 25000$ while examining spatio-temporal changes in seagrass cover in Urbinu, a Mediterranean lagoon. These changes in seagrass aerial coverage are primarily based on our biocenotic cartography carried out in 1997 and onto which we superimposed two other cartographies carried out in 1990 and 1994. This particular survey is interesting because during the period concerned (1990-1997), this part of the coast was exposed to a climatic change, which lasted eight consecutive years.

\section{Materials and methods}

\subsection{Study location}

The Urbinu Lagoon is one of the largest and deepest coastal lagoons $\left(135 \mathrm{~km}^{2}\right.$, depth of $\left.10 \mathrm{~m}\right)$ in Corsica; northern Mediterranean Sea (Fig. 1). The connection with the sea is by a grau regularly maintained, located to the east. The fresh water contributions intervene preferentially in the north-western part of the lagoon by the intermediary of small brooks, and streams of rainwater. All around the lagoon, the pozzi, temporary marshes and mudholes, collect water from the area catchments before rejecting it into the lagoon. Urbinu Lagoon is classified as a soft-bottom ecosystem whose shallow subtidal regions are dominated by seagrass meadows. Three species of seagrasses are found: Cymodocea nodosa (Ucria) Ascherson, Zostera noltii Horneman and Ruppia cirrhosa (Petagna) Grande (Agostini et al., 2002).

\subsection{Aerial photographs and mapping}

Image processing is based on three aerial color photographs (1/25 000 scale) taken in 1990, 1994 and 1997 by National Geographical Institute (IGN), following the tech- nical specifications described by Lefevre et al. (1984). For each year, mapping was carried out by different cartographers, but always using the same method defined by Pasqualini et al. (1997), with an accuracy of $2 \mathrm{~m}$. In parallel, several essential dives were conducted using scuba equipment over the whole study area, which allowed us to identify the nature of the assemblages and sea bottom. These ground-truths (field sampling) were carried out using the transect method and specific identifications. Thus, the main aquatic benthic assemblages and bottom types taken into account were: (i) soft sediments (mud and sand), (ii) hard substrate (pebbles), and (iii) seagrass beds. Synthesis of the data obtained from the aerial photographs and field sampling was carried out using the Multiscope software in order to generate a single map.

\subsection{Change detection}

Historical data concerning long-term changes in seagrass beds in the Urbinu Lagoon were obtained from previous work: the first biocenotic cartography was performed in 1990 by Fernandez (in Agostini, 2001), and the second in 1994 by Pasqualini et al. (1997). These two maps were produced with the same image processing that was used for our work. They were digitalized, integrated in our study, and the three biocenotic maps were superimposed using Adobe Photoshop software (Adobe Systems Incorporated ${ }^{\circledR}$ ), to give maps of temporal and spatial changes for the seagrass meadows. The total surface area of the seagrass meadows studied was calculated from the maps integrated in the Adobe Photoshop software. Entering all the cartographic data into the computer, the number of pixels of each topic allowed the evaluation of the surface according to the color of the various habitat types studied.

\section{Results}

\subsection{Surface and map comparisons}

The image processing technique with additional field data, provided maps showing the horizontal distribution of the different habitats (unvegetated: sand, mud, pebbles; and vegetated: seagrasses) along the Urbinu Lagoon (Fig. 1 for 1997), estimated at $76 \%$ reliability (using the reliability scale established by Agostini et al., 2002). It is possible to discern from the various maps three situations, which permit a description of the general scenario of temporal fluctuations of these habitats. These three surveys allow us to calculate the area of the variable cover from year to year, and to evaluate the respective percentages (Table 1).

In 1990, mud occupies the majority of the funds $(73.4 \%$ of the total area), while seagrass meadow accounts for only $18 \%$. In 1994, an evident decline of the seagrass meadows appears, giving way to mud (increasing up to $77.7 \%$ of the total area), and sand. In 1997, the situation is exceptional 


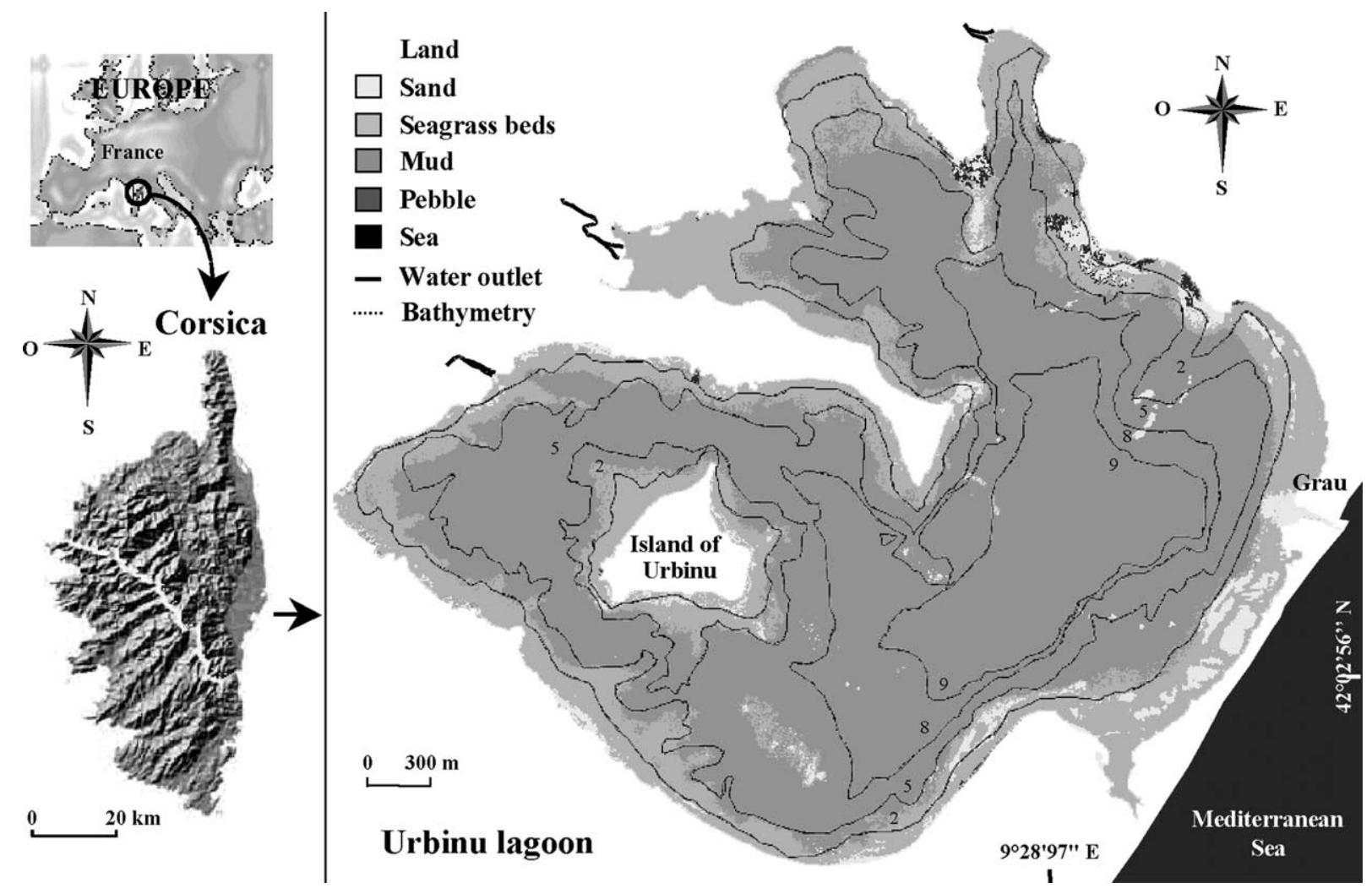

Fig. 1. Location and biocenotic map of the Urbinu Lagoon on the French Mediterranean coast in 1997.

with the appearance of an intensive recovery by the seagrasses (reaching $28.7 \%$ of the total area). The lowest variations of surfaces are raised between 1990 and 1994. Indeed, we can observe a reduction in seagrass surfaces of $3.5 \%$ and sandy surfaces of $1 \%$ (i.e. a total surfaces of $4.5 \%$ ). During the same period, muddy and pebbled surfaces increase by 4.3 and $0.2 \%$, respectively (i.e. a total of $4.5 \%$ ). These results show a slight silting of the funds, with passing of the seagrass meadows during the 4-year-period. The greatest variations of surfaces are raised between 1994 and 1997. Seagrass surfaces present an increase of $14.2 \%$, whereas the surface of mud, sand and pebbles is decreased by $14.2 \%$ on the whole $(11.1,2,1.1 \%$, respectively). These results show that over the 3-year-period, the seagrass meadows have strongly recolonized the area. On the whole, the seagrass meadows were estimated as comprising about 128.6 ha in 1990 and 205.3 ha in 1997. This area increased to $10.7 \%$ during this period.

\subsection{Spatio-temporal changes}

By superimposing the various limits of the seagrass meadows within the Urbinu Lagoon obtained for each year (1990, 1994 and 1997), we revealed the cartography of the spatio-temporal changes (regression, progression and stability) of these patterns over 7 years (Fig. 2). For each phenomenon observed, surface areas are calculated and deferred on Table 2 according to the period studied.

Between 1990 and 1994 (Fig. 2) dynamic meadows are characterized by a strong regression $(11.5 \%)$ on the northern and western sides of the lagoon, and around the island. These zones correspond to the soft water inlet $(\mathrm{A}, \mathrm{B}, \mathrm{C})$ of the catchment area towards the lagoon. The progression is observed in a uniform way on the lagoon (5.9\% of the total surface). In the eastern, south-eastern and north-western parts, the seagrass meadows remain stable $(13.2 \%)$. Between 1994 and 1997 (Fig. 2), dynamic meadows are

Table 1

Total area of each habitat category that changed between 1990 and 1997

\begin{tabular}{llllllr}
\hline Habitat & 1990 & & 1994 & & \multicolumn{2}{c}{1997} \\
\cline { 2 - 7 } & Surface (ha) & Percentage (\%) & Surface (ha) & Percentage (\%) & Surface (ha) & Percentage (\%) \\
\hline Seagrasses & 128.6 & 18.0 & 103.9 & 14.5 & 205.3 & 28.7 \\
Mud & 524.6 & 73.4 & 555.3 & 77.7 & 475.7 & 66.6 \\
Sand & 51.5 & 7.2 & 44.0 & 6.2 & 29.7 & 4.2 \\
Pebbles & 9.8 & 1.4 & 11.3 & 1.6 & 3.8 & 0.5 \\
Total & 714.5 & 100 & 714.5 & 100 & 714.5 & 100 \\
\hline
\end{tabular}




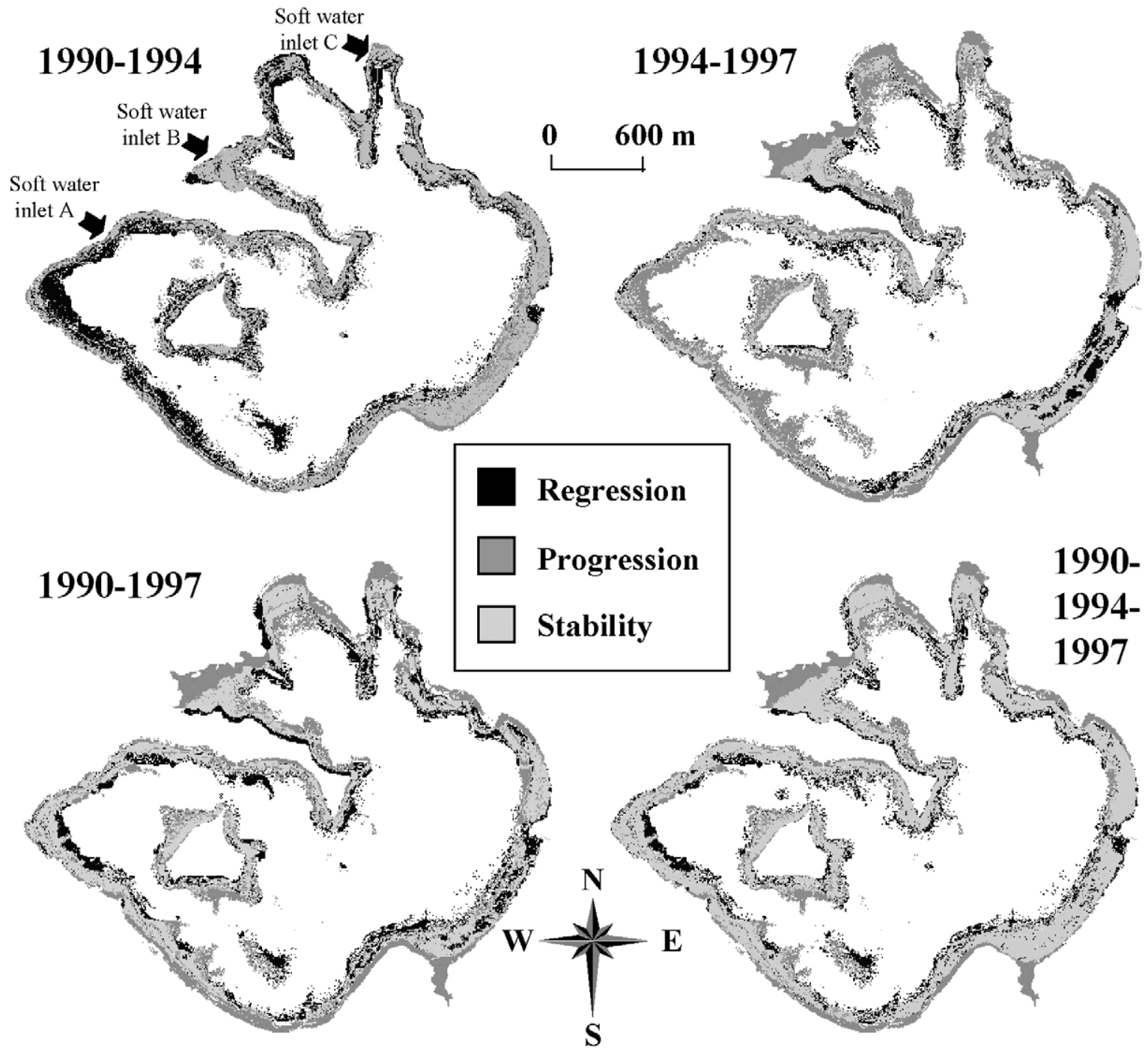

Fig. 2. Spatial changes of seagrass meadows in the Urbinu Lagoon (evolution and regression of 1990-1997): 1990-1994, comparison of the cartographies of 1990 and 1994; 1994-1997, comparison of the cartographies of 1994 and 1997; 1990-1997, comparison of the cartographies of 1990 and 1997 ; 1990-1994-1997, evolution from 1990 to 1997.

largely characterized by a strong progression $(16.3 \%)$ generally located in southern, south-western, western and northern parts of the lagoon, and around the island. Seagrass stability (11.8\%) was observed on south-eastern and northwestern parts. Regression zones are observed in the south ern, south-eastern and northern parts, but remain weak
(6.6\%). Between 1990 and 1997 (Fig. 2). By superimposing the two cartographies of 1990 and 1997, we can observe little difference between the three superimposed cartographies of 1990, 1994 and 1997, with regards positioning of the meadows and their dynamic. This dynamic is characterized by a strong stability of the settlements $(15.3 \%)$ located

Table 2

Temporal changes in the seagrass meadows between 1990 and 1997

\begin{tabular}{|c|c|c|c|c|c|c|c|c|c|}
\hline \multirow[t]{3}{*}{ Category } & \multicolumn{3}{|l|}{ 1990-1994 } & \multicolumn{3}{|l|}{ 1994-1997 } & \multicolumn{3}{|c|}{ 1990-1994-1997 } \\
\hline & \multirow[t]{2}{*}{ Surface (ha) } & \multicolumn{2}{|c|}{ Percentage } & \multirow[t]{2}{*}{ Surface (ha) } & \multicolumn{2}{|c|}{ Percentage } & \multirow[t]{2}{*}{ Surface (ha) } & \multicolumn{2}{|c|}{ Percentage } \\
\hline & & $\left(\%^{\mathrm{a}}\right)$ & $\left(\%^{\mathrm{b}}\right)$ & & $\left(\%^{\mathrm{a}}\right)$ & $\left(\%^{\mathrm{b}}\right)$ & & $\left.(\%)^{a}\right)$ & $\left(\%^{\mathrm{b}}\right)$ \\
\hline Regression & 82.0 & 11.5 & 37.6 & 47.5 & 6.6 & 19.2 & 66.4 & 9.3 & 24.7 \\
\hline Progression & 42.3 & 5.9 & 19.3 & 116.3 & 16.3 & 46.9 & 93.2 & 13.0 & 34.7 \\
\hline Stability & 94.3 & 13.2 & 43.1 & 84.0 & 11.8 & 33.9 & 109.0 & 15.3 & 40.6 \\
\hline Total & 218.6 & 30.6 & 100 & 247.8 & 34.7 & 100 & 268.6 & 37.6 & 100 \\
\hline
\end{tabular}

\footnotetext{
a Total lagoon surface ratio
}

b Total seagrass surface ratio 
in the middle of the meadows, followed by a progression zone $(13 \%)$ around twice as high as the regression zone $(9.3 \%)$ located at the superior and inferior limits of the meadows.

\section{Discussion}

We can observe that the seagrass meadows occupy, on the whole, the same geographical situations (subtidal zone) on the three cartographies. However, some differences in seagrass cover were detected according to the years, suggesting that the total extent underwent environmental disturbances. Fluctuations observed in the seagrass meadow extent between 1990 and 1994, and the various surface areas estimated specify that the bottoms of the lagoon seem to be physically more unstable. This lagoon is, therefore, making subject matter from greater sedimentation of fine particles (possibly due to a saline shock of great discharges of soft water charged with terrigenous particles and dissolved substances; Pearson and Rosenberg, 1978; Bellan and Bourcier, 1984) which, unfixed, remain removable on the surface of the sediment. However, seagrasses are sensitive to the sedimentation, which generates the recovery of the plant, also loss of luminous resource, essential to its development (Sand-Jensen, 1989; Middleboe and Markager, 1997). The strong regression of the meadows, observed between 1990 and 1994, are located near soft water inlets of the catchment area towards the lagoon. The mortality (or the disappearance) of these seagrasses could be explained by a significant and brutal change of salinity and temperature, which occurred during the large inundations throughout this period in Corsica.

The healthy development of the meadows between 1994 and 1997 is easily explained. Since after a return to normal precipitations and soft water inlets, the balance is restored within the ecosystem, and the meadows which had moved back in 1994 have only to recolonize the zones they had lost. By superimposing the two cartographies of 1990 and 1997, we can observe that there is little difference with those of 1994-1997, with regards the positioning of the meadows and their evolution. This confirms our assumption, according to the disturbance which generates the strong regression of the meadow boundaries after 1990 and before 1994. This assumption is reinforced by the results obtained from meadow areas which clearly decreased in 1994 compared to the two other years studied. This also highlights the speed of recolonization of these meadows, since they needed a maximum of 3 years to return to their original state (or almost). However, the regression zones are more developed than those presented on the map of 1994-1997. This fact suggests that they correspond to the origin zone of meadows before the inundations, which were not yet recolonized. On the other hand, the evolutions correspond well to newly colonized surfaces, which suggests that the meadows are in good health, and that nothing interferes with their develop- ment, perhaps even that this development is supported by certain terrigenous contributions.

Despite these environmental perturbations, the seagrass phanerogames revealed the extraordinary recolonization of the habitat. In spite of the variations noticed between 1990 and 1997, we observe a stability of the seagrass population during the last 7 years. This coincides with the theory proposed by Guelorget and Perthuisot (1992) concerning the stability of the paralic populations, as: the more an ecosystem is implanted in an unstable habitat the more it is stabilized by a rapid phenomenon of the reestablishment of perturbed ecosystems. The parameter and the depth play an important role in the rapidity of confinement of the basin which flows away from the sea. We can say that the deeper the paralic basin, the slower its biological reaction and exchange with the sea. This is indeed the case with our lagoon which is the deepest in Corsica $(-10 \mathrm{~m})$.

\section{Conclusion}

This work allowed us to study the seagrass settlements on movable substrates in the Urbinu Lagoon. Aquatic phanerogames were the predominant habitat and the only seagrass species found in the lagoon. Thanks to previous work on our study by the same method of image processing and field data, we could observe the possible evolutions of these meadows for this lagoon between 1990 and 1997. The results show a reduction of the seagrass surfaces as well as a progressive silting of the lagoon in 1994, generated by the inundation observed before this period. Comparison of habitat maps (1990, 1994 and 1997) represents the first comprehensive assessment of seagrass distribution in Urbinu Lagoon. Thus, our study represents a richness of information for the knowledge of different vegetable biocenosis found on this lagoon, like their space and temporal distribution. This work may constitute a reference for future studies.

\section{References}

Agostini, S., 2001. Contribution à l'étude des herbiers à phanérogames dans les étangs de Corse. Thèse de Doctorat, Université de Corse, 258.

Agostini, S., Capiomont, A., Marchand, B., Pergent, G., 2002. Distribution and estimating basal are coverage of subtidal seagrass meadows in a Mediterranean coastal lagoon. Est. Coast. Shelf Sci. (in press).

Bellan, G., Bourcier, M., 1984. Bilan écologique du détournement permanent d'un petit fleuve côtier dans l'émissaire d'eaux usées d'une grande ville. Mar. Environ. Res. 12, 83-111.

Cambridge, M.L., Hocking, P.J., 1997. Annual primary production and nutrient dynamics of the seagrasses Posidonia sinuosa and Posidonia australis in south-western Australia. Aquat. Bot. 59, 277-295.

Den Hartog, C., 1987. "Wasting disease" and other dynamic phenomena in Zostera beds. Aquat. Bot. 27, 3-14. 
Grauby, H., Augier, H., Lion, R., Charlent, O., 1991. Neutron activation analysis of elemental composition in marine phanerogam, Posidonia oceanica (L.) Delile: a biological indicator of pollution. Environ. Exp. Bot. 31 (3), 255-263.

Guelorget, O., Perthuisot, J.P., 1992. Paralic ecosystems: biological organization and functioning. Vie Milieu 7, 2-11.

Kuo, J., Phillips, R.C., Walker, D.I., Kirkman, H., 1996. Seagrass Biology. Sciences UWA Publ., University of Western Australia, Ned lands, WA 6907 (p. 366).

Lefevre, J.R., Valerio, C., Meinesz, A., 1984. Optimisation de la technique de la photographie aérienne pour la cartographie des herbiers de Posidonies. In: Boudouresque, C.F., Jeudy de Grissac, A., Olivier, J. (Eds.), International Workshop Posidonia oceanica Beds, vol. 1. GIS Posidonie Publication, France, pp. 49-55.

Middleboe, A.L., Markager, S., 1997. Depth limits and minimum light requirements of freshwater macrophytes. Freshwat. Biol. 37, $553-568$.
Pasqualini, V., Pergent-Martini, C., Fernandez, C., Pergent, G., 1997. The use of airborne remote sensing for benthic cartography: advantages and reliability. Int. J. Remote Sens 18 (5), 1167-1177.

Pergent, G., 1991. Les indicateurs écologiques de la qualité du milieu marin en Méditerranée. Oceanis 17 (4), 341-350.

Pearson, T.H., Rosenberg, R., 1978. Macrobenthic succession in relation to organic enrichment and pollution of the marine environment. Oceanogr. Mar. Biol. Annu. Rev. 16, 229-251.

Rasmussen, E., 1977. The wasting disease of eelgrass (Zostera marina) and its effects on environmental factors and fauna. In: Mc Roy, C.P., Helfferich, C. (Eds.), Seagrass Ecosystems: A Scientific Perspective. Marcel Dekker, New York, Basel, pp. 1-51.

Sand-Jensen, K., 1989. Environmental variables and their effects on photosynthesis of aquatic plant communities. Aquat. Bot. 34, 5-25. 